\title{
TURKEY'S KURDISH QUESTION: OPPORTUNITIES AND PREDICAMENTS
}

\author{
CinAT YilmaZ ${ }^{1}$ \\ Vytautas Magnus University (Lithuania)
}

\begin{abstract}
Since the foundation of the Republic of Turkey, the Kurdish question has been the biggest ethnic issue of Turkey which became one of the important subjects in the agenda of Turkey and international organizations. The question has certain impacts on the stability of the country that is today being associated with security and terror issues. Consequently the Kurdish question challenges the state and the country in the aspects of ethnic problems, human rights, democracy, as well as socio-economic and political. The aim of this article is to uncover how the Kurdish question challenges the stability in terms of Turkish state and the Kurds. In this regard, the research engages several objectives; evaluations of approaches toward Kurdish issue, analyzing historical background, and evaluation of the issue in the present time. Research methods of the paper consists of comparative analysis of decision, document analysis on the reports and agreements, descriptive method on the developments, and media analysis to engage relevant news. The main results of the research are concluded on variety aspects of the Kurdish question, such as security, terrorism, minority issue, human rights, and so on. Thus, it creates certain impacts on the stability in Turkey both in terms of state and the Kurds regionally and internationally. KEY WORDS: Turkey, Kurds, PKK, Ocalan, AKP
\end{abstract}

JEL CODES: K1, D74, D78

DOI:

Introduction

Kurds are known to be the biggest ethnic group without state in the world. They make up about $10 \%$ in Syria, $19 \%$ of the population of Turkey, $15-20 \%$ of the population of Iraq and are the second largest ethnicity in Iran (edition.cnn.com). The Kurds form the largest ethnic group in Turkey, (Institut Kurde de Paris, 2017) mostly in eastern and south-eastern of the country. Kurdish question is one of the Turkey's ethnic issues that have not been solved over a century. The issue has been identified in variety of ways including terrorism, economic instability, education, identity and so on. Prior to the foundation of the republic, the Treaty of Sevres ensured the Kurdish autonomous territory (Treaty of Sevres, 1920), however such demands were disavowed in Lausanne. Eventually the Lausanne treaty drew the current border of the modern Turkey (Lawrence, 1924:989), and the republic was established on the principles of one nation, one flag, and one language (Constitution of Republic of Turkey: 2, 3). Such developments then consequently led the uprising emerged among the Kurds in different years. Sheikh Said (Arfa, 2006:48), Ararat, and Dersim (Kutschera, 2013: 113,148) rebellions are one of the most influential uprisings demanding the autonomous rights of the Kurds from 1925 to 1938. Thus, the Kurdish question came forth and has become one of the prominent ethnic issues. It is also crucial to mention Dersim and Zilan massacres (Mikaberidze; 2013: 746) following some the uprisings.

After a stagnation period, the Kurdish mobilization against the state once again appeared on the scene in 60 s. Several organizations were founded on different strategies yet on the same question. On the other hand, the state perpetuated its policy against the Kurds using different tools, such as language, culture, and identity. Moreover, the 80's was relatively one of the most difficult stages of the modern Turkey. By the coup in 1980,

Cihat Yilmaz- PhD student at the Vytautas Magnus University, Faculty of Political Science, Regional Studies

Scientific interests: ethnicity, nationalism, Kurdish question, oriental studies

E-mail: cihat.jan.yilmaz@gmail.com 
the military has taken power over the country and eliminated almost all the ideological circles, including leftists, Islamist, and all the Kurdish organizations that had emerged before (Cormier; 2014: 18). However, few years after the coup, the Kurdistan Workers Party (PKK) which was found in 1978, initiated its first armed campaign against Turkey in 1984 (Encyclopedia Britannica; 2020). With the actions of the PKK, the Kurdish question has gone through certain stages that led the state engage military forces. Although there have been several alternatives to bring a solution to this question, the attempts from both sides the Kurdish political entities and the state, were inconclusive. Despite the initiatives taken in 2009, the unsuccessful strategies led to another conflict era, such as Trench operations in 2015 (International Crisis Group; 2020). Evidently, the question still remains as an unsolved ethnic problem of Turkey.

Objectives of the research: Socio-political, historical, and ideological factors that caused the Kurdish question in Turkey from the foundation of the republic to the present time.

The aim of this research is to discover how the Kurdish question challenges the stability in the country in terms of both the state and the Kurds.

In order to achieve this aim, the tasks were formulated as:

1. Analysis of approaches toward defining the Kurdish question;

2. Reviewing the historical background of the issue;

3. Analysis of the Kurdish issue in contemporary Turkey.

Main questions of the research: Although the questions of the research are basically constructed on the objectives it is useful to point out the crucial ones, as follows:

1. What is the socio-political, historical and ideological background of Kurdish issue?

2. How does the PKK change the perceptions towards defining the Kurdish question?

3. How does the Kurdish question challenge the stability in the country?

Research methodology: The methodology of case study is used as it involves analysis of person, group, and events. As case study also analyzes decisions, periods, policies, institutions or other systems that are studied holistically by one or more methods (www.pressacademia.org), therefore, this research also involves the analysis policies in different times, institutions and their decisions on certain events, as well as the periods of the events. The analysis of the research is based on empirical research methods. A comparative method is conducted for the comparison between the tendencies regarding the development of the issue. The method also helps to reveal the approaches toward the issue in terms of identity, social, and political means. In order to find out how various agreements, documents, decisions, and reports were significant for the case, it is carried out the analysis of the documents. Finally, the qualitative content analysis to examine the events and developments and media analysis to engage the news that is related to the events were conducted.

\section{Defining the Kurdish Question}

Scholars, policy makers, international observers and organizations have analyzed the Kurdish question within the frameworks of either their own policies, ideologies, sentiments, or taking some certain events into account as a core theme of the issue. The fact that the Kurds in Turkey going through different historical stages and experiencing variety of the events, such as uprisings, massacres, denial of their identity, oppressions on cultural rights; their interaction with different social groups and being deprived from self-determination, crates a complex background to what extent the issue is being addressed. Including ethnic and cultural rights, security issues, education and economic challenges, all in all makes certain relevancy to engage the question in the past and the present. Thus, analyzing the Kurdish issue, it is crucial to take approaches into account, including security, human rights, democracy, freedom, identity, and in national spheres. However, it is also an undeniable fact that the Kurdish issue has been and is being assessed as an ethnic conflict between the state and the Kurdish separatist groups, such as PKK (Kurdistan Workers Party) which was founded by Abdullah Ocalan in 1978 in Turkey on Marxist-Leninist ideology and actively operating armed conflict against Turkey.

Despite the rhetoric based on the conflict, Martin van Bruineissen suggests that it is not right to see the Kurdish problem as a conflict between Kurds, Arabs or Turks, or between Kurds and central government. 
He claims that Kurdistan is a complex society with many internal conflicts and competition; these problems are further aggravated by state-level economic changes and political conflicts. Their local relationships and conflicts have been linked to state-level and inter-state-level conflicts, and different forms of intensive cooperation have developed between local rulers and the state apparatus (or another state-like actor, the Kurdish movement). All this makes it difficult to make a clear distinction between state pressure and local forms of pressure (Bruineissen; 2000: 10, 11). Unlike Bruinessen, Turkish sociologist Ismail Besikci analyzes the Kurdish issue as a colonial case. Besikci states that today Kurdistan is an international colony in the middle of the Middle East. Turkey, Iraq, Iran, Syria's colonial partners. Even the status of the Kurdish nation is much lower than the colonies. For example, the existence of Kurds in Turkey is not allowed to spell. Every effort is made to crush, dissolve and destroy the Kurdish personality and Kurdistan personality. The fact that the Kurds are treated equally with the Turks is subject to the condition of Turkification. This is racist, which is unique in the world. And it is colonial (Besikci; 1991: 32).

Although the PKK movement made many alternations in its ideology towards the Kurdish issue in Turkey and the Middle East, the first guiding book of the movement addresses the issue as colonial problem which demonstrates the foundation of the Turkish Republic as an image that the chauvinist character of the new regime has made it clear that any justified claim that expresses the interests of the Kurds will be forcibly suppressed (Ocalan; 1993: 80). Thus the only solution alternative is seen in democratic independent Kurdistan. However, the PKK later announced the issue on a 'democratic civilization' platform in which the PKK's leader Abdullah Ocalan submitted "Democratic Unity Solution Theses" where he invites both parties to strengthen the state's unity by obliging to the principles of democracy (Ocalan; 1999: 85). In parallel to this, the pro-Kurdish party, HDP (People's Democratic Party) also started to evaluate the Kurdish question as an issue of democracy, peace, and collective rights. The HDP also put in its agenda that it is necessary to struggle to ensure a permanent peace in the Kurdish problem, which has been left to the deadlock, and to resolve all the problems of the Kurdish people within the scope of collective rights (People's Democratic Party: Article 2).

Apart from defining the issue, time to time Turkish officials have denied the very existence of an issue; as the President of Turkey, Erdogan stated in 2018 election rally in Diyarbakir that he did not say that the Kurds do not exist, but the Kurdish question does not (Amerikanin Sesi; 2018). However, in one of his speeches in Diyarbakir in 2005, Erdogan openly expressed that the Kurdish problem is his problem as well as a problem of all the citizens in the country (BBC; 2005). Also, the former President, Abdullah Gul, to an interview stated that the Kurdish problem is Turkey's first problem. Saying that "there will be good things about the Kurdish issue," Gul also said that whether it is called terrorism, south-east issue, or Kurdish issue, this is the first problem of Turkey. It is necessary to be addressed (Milliyet: 2009).

In the past years, Turkey's progress reports prepared by the European Commission have addressed several issues regarding the political, social, and economic frames in which Turkey has been criticized for not obliging to the principles of the European Court of Human Rights. However, some reports do not directly address the issue as "Kurdish question" but under the article of Human Rights and Protection of Minorities. Indeed, the minorities of Turkey do not consist of only the Kurds but Armenians and other Christian minorities as well. But if the Kurdish issue is viewed through the prism of human rights and minorities' rights, it is undeniable that they are the direct interlocutors of the analysis. From 2010 to 2019, Turkey is being criticized for violating the ECHR. During the reporting periods the court delivered a total of 553 judgements in 2010 (European Commission; 2010). These numbers decrease to 4018 and the report also includes that the state had violated the right to freedom of assembly and association by the ban of the pro-Kurdish party, the People's Democracy Party (European Commission; 2011).

In the following year, the European Commission sought the Kurdish issue as an issue of democracy. In fact, Turkey's democracy, in general, is a matter of question. Especially at the time of the AKP (Justice and Development Party) and Erdogan's presidency, it has created concerns on whether the Turkish state is a democratic or an authoritarian state. According to Sustainable Government Indicator's report of 2019, gender-based violence and discrimination, and hate speech and human rights violations against minorities (e.g., LGBTI persons) are serious concerns. The transition to a presidential institutional mode was implemented 
by decree rather than through legislation, as required by the constitution. Corruption remains widespread (www.sgi-network.org). The Democracy Index of the Economist places Turkey's score as above 5 until 2017 and fell to 4.88 in 2017, stood as 4.37 in 2018, falling under the category of "hybrid regime," the second lowest after "authoritarian regime," putting Turkey in a similar position to countries such as Ukraine, Zambia, Mali, Tanzania, Madagascar, Honduras, and Bolivia (stockholmcf.org). Regarding the Kurdish question, the European Commission suggests that the Kurdish issue remains a key challenge for Turkey's democracy, concerning the initiative that was not followed up and the 2009 democratic opening, aimed at addressing amongst others the Kurdish issue, was not followed through (European Commission; 2012). On the other hand, legalizing Kurdish language in public services as recommended by the Council of Europe's Congress of Local and Regional Authorities (European Commission; 2013), allegations on misusing the state resources for the benefit of the Prime Minister in the election, and fraud sparked protests in a number of cities (European Commission; 2014) which are Kurdish populated due to the HDP; resuming the Kurdish peace process as a matter of urgency (European Commission; 2015), concerning a law allowing the immunity of a large number of deputies to be lifted and the ensuing detentions and arrest of several HDP Members of Parliament (European Commission; 2016), and many serious backsliding of human and fundamental rights have been the issues of the European Commission directly or indirectly related to the Kurdish question in Turkey. Thus, it brings an understanding to view that the Kurdish issue has been defined by the events developed in the country and an unsolved problems within.

In sum, the complex structure of the Kurdish question remains on uncertainties that make it even more difficult not only in case of understanding the character of the issue but also in case of bringing solutions to the question. As a matter of fact, being the largest ethnic minority in the country can cause more than just an ethnic problem. It also reflects economic situation in east and south-eastern regions (northern Kurdistan), educational, religious, and cultural dilemmas. All in all, having different dimensions, the Kurdish issue has been engaged in different approaches.

\section{The Roots of Kurdish Question}

Although the Kurdish question is perceived as a modern phenomenon, a Kurdish poem Ehmedê Xanî (Ahmed-i Khani, 1650-1707) reflected the issues of the Kurds in his famous book, Mem u Zin, in $17^{\text {th }}$ century. Expressing his thoughts and complaints of unity and statehood, Xanî clearly demonstrates the necessity of a strong Kurdish leadership and territorial sovereignty as only ways of ending the sorrow of the Kurds:

Ez mame di hikmeta Xwedê da - I am surprised with the favor of God

Kurmanc di dewleta dinê da - that the Kurds in this world

Aya bi çi wechî mane mehrûm - Why are they desperate?

Bilcimle jibo çi bune mehkûm - why are they all captives?

(..)

Bifikir ji Ereb heta Gurcan - Think of the Arabs and the Georgians

Kurmanciye buye şibhê bircan - it is the Kurds who stands like a front

Ev Rum û Ecem bi wan hesarin- those Rums (Turks) and Ajams (Persians) are like block

Kurmancî hemi li çar kenarin - the Kurds have dispersed all over the world (Bozarslan; 1968: 15)

Explaining the situation in which the Kurds live, Xanî also presents an alternative for the 'salvation' of the Kurds suggesting a strong leadership, as:

Ger dê hebuwa me serfirazek- If we had a successful one

Sahibkeremek sexunûwazek- a genereous a wise one

Xemxarş di kir li me yêtîman- he would pity us the orphans (Kurds)

Tînane derê ji destê leîman- he would save us from the cursed ones

Herçi bide şûrê destê hîmmet- whenever he takes the sword of power

Zebt kir ji xwera bi mêrî dewlet- he will take over a state like a man (Bozarslan: 20) 
Xanî is believed to be the father of Kurdish nationalism. However, such Kurdish nationalist discourses came into action after two centuries by Sheikh Ubeydullah Nehri's unsuccessful uprising in 1880 (Library of the Congress; 2011: 8445) against both Ottoman and Persian states known as the first Kurdish nationalist movement aiming to self-determination. Following to the collapse of the Ottoman Empire and prior to the declaration of the modern republic of Turkey, a Kurdish aristocrat, Sharif Pasha, presented a map to the committee in Paris Peace conference where he drew a map suggesting the Kurdish autonomous territory including the south-east and eastern region of Anatolia starting from Mosul (Izady; 1992: 60). In the following year, the idea of Kurdistan and the territory was ensured by the Treaty of Sevres with the map lying east of the Euphrates, south of southern boundary of Armenia as an autonomous Kurdish state (Lawrence; 1924: 807). The treaty also ensured that 'if any renunciation takes place, no objection will be raised by the Principal Allied Powers to the voluntary adhesion to such an independent Kurdish state of the Kurds inhabiting that part of Kurdish which has hitherto been included in the Mosul vilayet (Lawrence: 808).

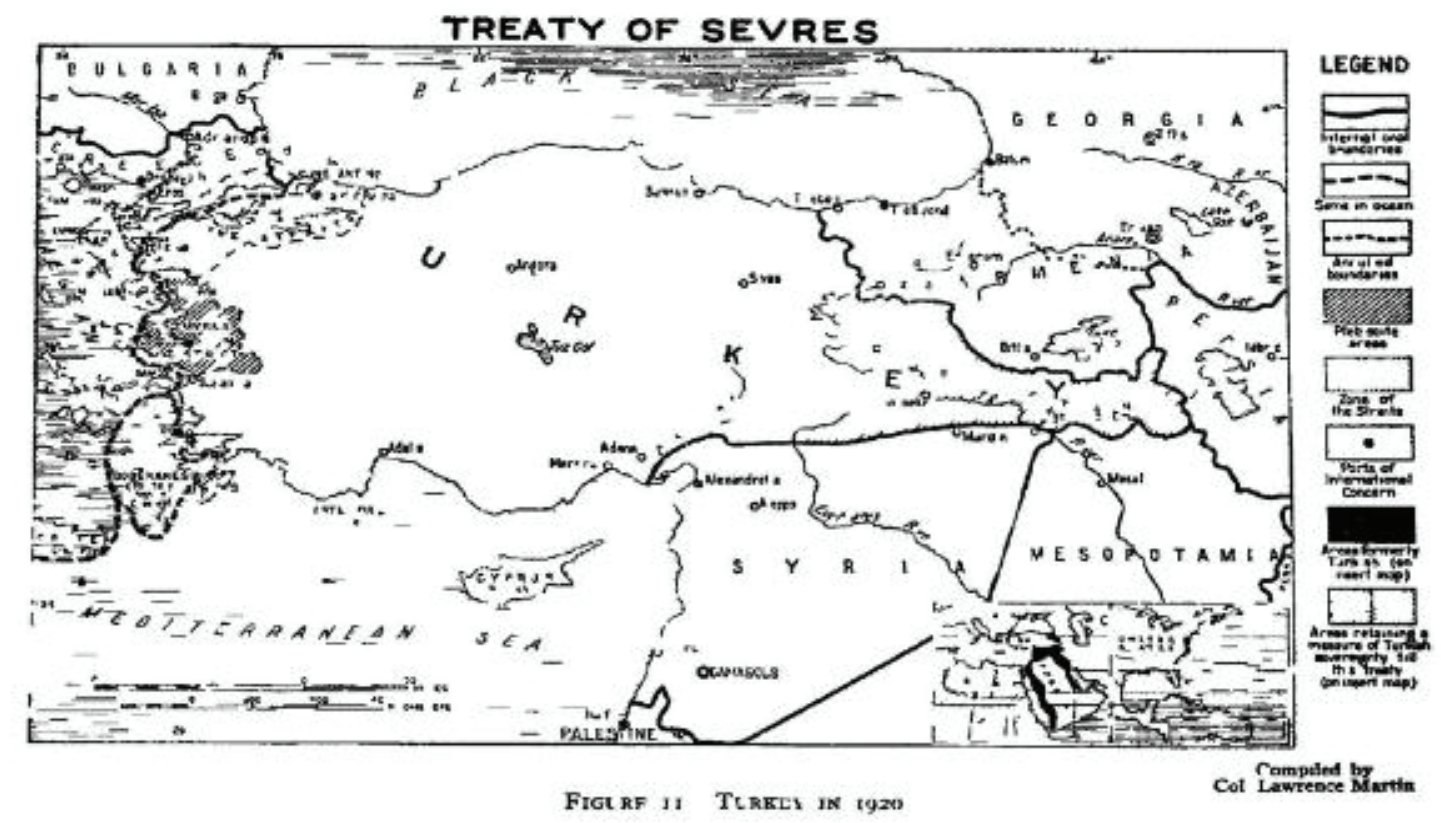

Figure1: Turkey's border according to Treaty of Sevres (Lawrence: 789)

Despite ensuring the Kurds' right of self-determination and expansion of the territory of Armenia in the Sevres, the Lausanne drew the current borders of Turkey disavowing the principles of the Sevres.

Foundation of republic of Turkey loyal to the nationalism of Ataturk and the language to be Turkish only (Constitution of Republic of Turkey: Articles 2,3) clearly indicated the denial of any other minorities with their identity, cultural and linguistic rights. Thus, the Kurds found themselves to be isolated from any political representation in the country. Therefore, from 1925 to 1938, the state has faced several Kurdish uprisings, such as Sheikh Said rebellion in 1925 (Cagaptay; 2006: 105), Mount Ararat revolt, 1927 (Chaliand; 1993:54); and Dersim in 1938 (Chatty; 2010: 263) which were brutally suppressed resulting with massacres.

From 1938 until 60's, the Kurdish movements have been into a stagnation period. By the influence of Mustafa Barzani (1903-1979), the leader Kurdistan Democratic Party in Iraq, the Kurdish mobilization reappeared in Turkey with several organizations. It is worth mentioning that the view of these organizations toward the Kurdish issue varied on their ideological perspectives. For instance, while the Kurdistan Democratic Party-Turkey followed a strict nationalism, for the Labors Party the Kurdish issue was a part of 'suppressed proletariat'. Such ideological distinction sometimes led to inner-conflict among the Kurdish parties (Kutschera: 398-399). In fact, the intensity of the conflicts between the groups, including rightist, leftists, 


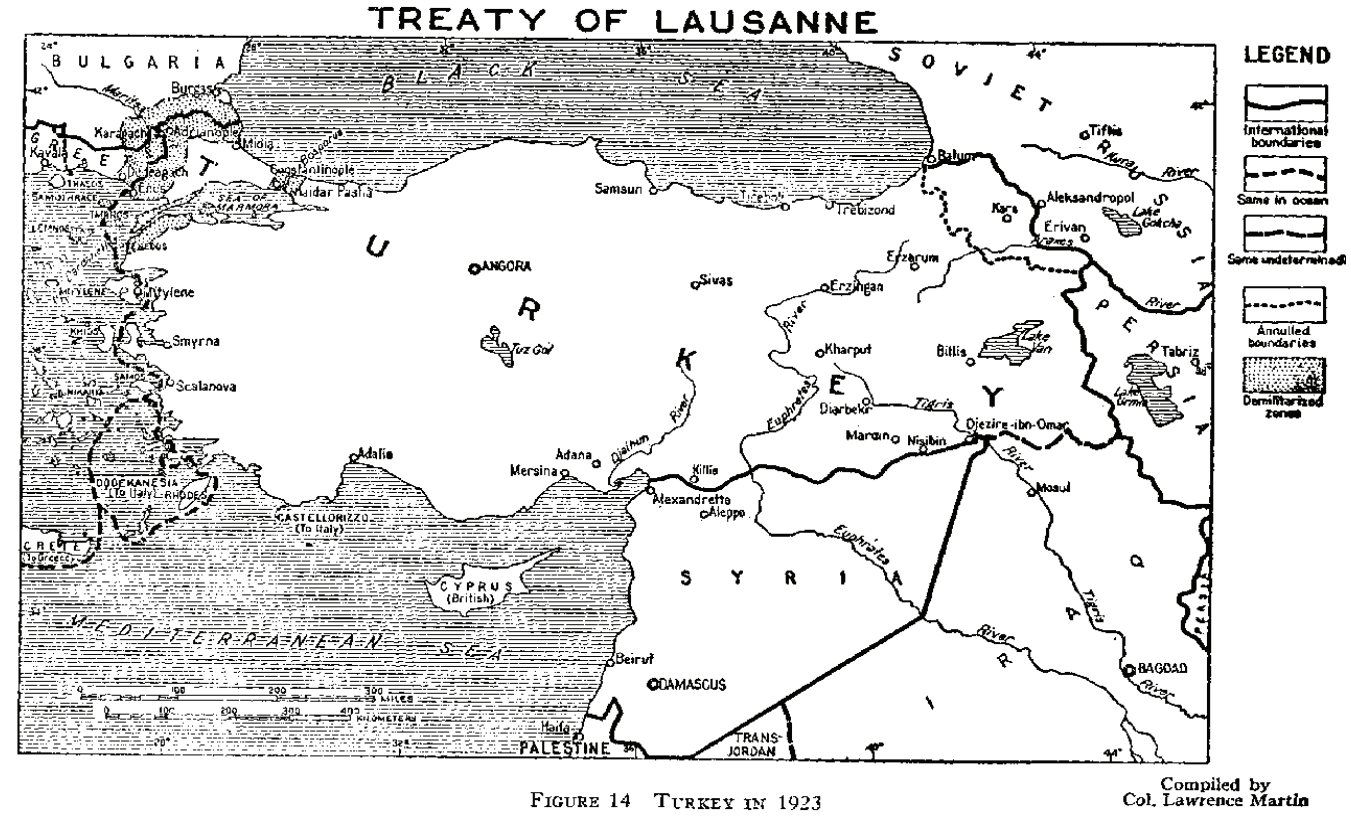

Figure 2: Turkey's original map in Treaty of Lausanne and the modern Tukey's borders (Lawrence: 808).

Kurds, and ineffectiveness of the government had Turkey experience a coup which the army took over the power and eliminated almost all ideological organizations. All political activists from radical groups, but principally left-wing groups, were prosecuted: “650,000 imprisonments for varying durations, often accompanied by ill treatment and torture, 1,683,000 judicial investigations, 517 death sentences) of which 49 were executed), 30,000 dismissals from the civil service, 14,000 individuals deprived of Turkish citizenship, the prohibition of 667 associations and foundations, hundreds of suspicious deaths" (Cornier; 2014: 18).

\section{PKK and Security and Terror Issues of Kurdish Question}

Founded by Abdullah Ocalan and his friends in 1978, the PKK showed a radical attitude toward the Kurdish issue generally in the Middle East and particularly in Turkey. As mentioned above, the PKK has sought the Kurdish question as a colonial case and therefore a democratic independent Kurdistan to be established as the only alternative (Ocalan; 1993: 127). In this regard, by its first armed action against the state in 1984, the organization was added to the list of terrorist organization not only by Turkey also by international organizations (Council Common Position; 2006: 28). In the end, the situation had led the Kurdish issue to be associated with terrorism both in the view of Turkish state and international community.

As the result of the conflict between the Turkish state and the PKK, 492 civilians, 1,231 state security force members, 226 individuals of unknown affiliation, and 2,895 PKK militants have been confirmed dead (International Crisis Groups; 2020). This conflict between the PKK and the Turkish state has added a new concept to define the Kurdish question; ethnic conflict. The PKK's vision on the armed struggle and finding support by the majority of the Kurds in the country results a status that is not only a conflict between the organization and the state. Eventually it also caused to bring the Kurds and the Turkish against each other. In September 2015, Evrensel newspaper has prepared a report containing attacks on the Kurds and the HDP building in different cities. According to this report, in 23 western provinces, the incidents took place against the HDP offices, Kurdish seasonal agricultural workers, construction workers, and people speaking Kurdish in the streets as both individual and group assaults (Evrensel: 2015). While this makes it clear that some 
Turkish people now have the belief of a problem of terror instead of a Kurdish issue, it also demonstrates the reality of a Kurdish-Turkish conflict.

The arrest of the PKK's leader Abdullah Ocalan was a turning point for the organization. Rather than the previous radical discourses, the organization developed relatively moderate approaches, such as peace, brotherhood of the people, and even expressing the support to the sovereignty of the state. In an interview given to The Economist, one of the leading cadres of the PKK, Cemil Bayik stated that they no longer wanted a separate state in Turkey. Alternatively he expressed that they supported cantonal and democratic confederalist system (Hurriyet: 2015). In the $7^{\text {th }}$ congress held in 2000 following the arrest of Ocalan, the PKK decided to prepare a comprehensive peace project and initiate the democratic political struggle. In the subsequent congress in 2002, it focused on the importance of identity, language and cultural right and to put them under the security of constitution. After that, it was announced in the $9^{\text {th }}$ congress that the armed struggle would be left and expected the mediation by the USA. Regarding the ideological change of the PKK, in the congress of 2005, it was decided to abandon the Lenninist model and adopt the idea of confederalism. In the congresses held in 2006, 2007, and 2013 that followed, decisions were made to adopt the EU law, to establish the HDP, and finally to adopt the idea of the system of democratic autonomy (Yenicag: 2015).

When the Democratic Solution Process initiated by the Turkish government in 2009 ended up inconclusively in 2014, the state and the PKK entered a new conflict era. Especially Turkey's operation to Kurdish district of Kobani in northern Syria created the first step of a new environment of violence in the near future. Since violence resumed in July 2015, the 33-year conflict with the PKK, which Turkey, the U.S. and European Union (EU) consider a terrorist organization, has devastated neighborhoods and livelihoods across urban districts of the majority Kurdish south east. In twenty one months, at least 2,748 died, around 100,000 lost their homes, and up to 400,000 were temporarily displaced (International Crisis Group; 2017: ii). Especially the southern district Nusaybin saw unprecedented violence in 2016, with a death toll of at least 184, of whom 24 were civilians. 12 Six of the town centre's fifteen neighbourhoods were fully destroyed; some 6,000 buildings were demolished or heavily damaged; around 30,000 people lost their homes (International Crisis Group: 4).

Taking into consideration all the events, the conflict between the PKK and Turkish state has a direct impact on the Kurdish issue. Especially when it comes to political participation it is possible to see the effects of the conflict clearly. The HDP, which is supported by the majority of the Kurds, is associated with the PKK and the PKK's open support of the HDP has shown the HDP as a political wing of the PKK. As a result, it was faced the risk of being shut down several times, and due to this association, co-chairs and some members of the HDP are currently being held in prison (Milliyet: 2016).

\section{Kurdish Question and Issues of Stability}

In case of any ethnic issue, the way that the issue is assessed on both sides, and therefore steps are taken to resolve the problem either through dialogue or political participation, and long time frame of such processes which also results in conflict, lead to many different problems in a country. The studies directed to the Kurdish question in today's Turkey have evaluated the problem generally in the framework of democracy, terror, cultural rights, and or human rights. The fact that all these and similar evaluations have their share of merit also shows how the Kurdish question has challenges and impacts across the country.

The security problem arising from the conflict environment and, in parallel, the evacuation of many settlements in the eastern and southeastern regions resulted in migrations to the major cities and western provinces. These migration events have brought with them many problems. According to the research work of Turkey Migration and Internally Displaced Population, due to the safety reasons, the population size in internal migration in Turkey between years 1986-2005 range about 953.680-1.201.200. In the period 19861995, when the migrations were intensified due to security reasons, $74 \%$ of the migrant population lived either in the city center of the same province or in the urban centers of the province where they migrated (Hacettepe, Center for Population Studies; 2016: 106-107). Consequently, the imbalance in the distribution 
of the population of the country, distorted urbanization, incapability in health, education and infrastructure, cultural conflict, environmental problems, problems in income distribution, increase in unemployment rate and as a result social problems such as theft and crimes are only some of the facts (Kocak; 2012: 169-170).

Another impact of Kurdish question in general and the PKK and security issues in particular is the employment case. Throughout the history of modern Turkey, the western provinces have been relatively in better conditions in economic terms compared to the eastern provinces. This, indeed, is closely related to the security factor in the regions. For instance, while calculating the employment rate in 2018 as 47.4, most of the provinces where the employment was increased are in the west, such as Samsun, Tokat, Corum, Amaysa, whereas the lowest employment rate is observed in Mardin, Batman, Sirnak, and Siirt which are Kurdish populated cities (Bloomberg: 2019). Some might consider the role of the private sector in this regard. That is why it is useful to express the investments made by the state according to the provinces. For example, in 2003, 2006, 2009, 2012, and 2015, the western provinces were the most invested once, while only three major cities in the eastern region; Diyarbakir, Mardin, and Sanliurfa (Head of Strategy and Budget: 2019). This situation also leaves questions about the fairness of investments made by the state which can also trigger another factor of the Kurdish question.

Besides the regional and socio-political and economical effects, it is also possible to see the impacts of the Kurdish problem on Turkey in international arena. This situation has an important position on the image of Turkey in the view of international organizations. The European Commission on its reports on Turkey, due to the violation of democracy and human rights directly or indirectly related to the Kurds, the state has been criticized and it has called on Turkey to find alternatives for the solution of the problems. In one of the reports, "Progress on the situation of Kurds in Turkey", The EU Commission clearly displayed its position regarding inconclusive progress on the Kurdish issue highlighting the need to respect the rule of law on ongoing trials of the Kurdish elected representatives and Kurdish activists, and therefore consistently called for a political solution to the Kurdish issue through inclusive democratic dialogue and constitutional reform (Library of European Union: 2013). In addition, the United Nation in its reports has also expressed the concerns regarding Turkey's policy on the Kurds and presented concrete solution alternatives; such as the Roma and the Kurds, facing a more difficult socio-economic situation than the rest of population, and hostile attitudes on the parts of the general public, including attacks and threats, towards Roma, Kurds and persons belonging to non-Muslim minorities (The United Nations; 2009:3-4); absence of a broad legislative framework for recognition of all minorities, including Kurds, Roma and Arameans (The UN: 2011: 3); discrimination and restrictions suffered by Kurds and Roma, affecting their rights to enjoy their own culture and use their own language (The UN; 2012: 2); and numerous credible reports of law enforcement officials engaging in torture and ill-treatment of detainees while responding to perceived and alleged security threats in the south-eastern part of the country (The UN; 2016:3).

\section{Conclusions}

The Kurdish question is one of the biggest ethnic problems in Turkey and has faced many challenges in socio-political and economic terms. Although studies conducted by different circles on the structure of the Kurdish question have generally dealt with a part of the problem, or have dealt with the situations arising directly or indirectly from this problem. The origin of the Kurdish question is in fact a situation that covers these assessments and is based on historical facts beyond them. Besides being the biggest ethnic problem in Turkey, it is also a problem developed with its own internal dynamics. These dynamics sometimes manifest themselves in a complex process of solving the problem. The view of different Kurdish circles toward the Kurdish question and their solution alternatives, rather than forming a unity among them, due to the ideological and strategic varieties, it creates a fragmented environment both politically and socially. The main factors in the Kurdish movements; nationalism, religion, and leftist ideology, causes a lack of representation, which is perhaps one of the biggest problems for the Kurds in today's Turkey.

Today, the association of the Kurdish question with the PKK and terrorism has an important role in shaping Turkey's policy towards the Kurds. Thus, Turkey's approach to the Kurdish problem with military apparatus creates an environment of conflict rather than a solution. That is because this climate of conflict, which has existed since 
1985, has caused great damage to both sides. Morover, the fact that the PKK has always tried to have monopoly on the other Kurdish groups, being supported by the majority of people, and the HDP following the same agenda as the PKK, when it comes to projects such as democratic confederalism, democratic autonomy, although it tries to approach in a diplomatic way, this relationship between the two organizations puts the HDP in a hard situation in the political participation. Thus, this image created both in the political sense and in the eyes of Turkish society constitutes the belief that the Kurdish question is developing only on the axis of terrorism.

The Kurdish question has important implications on the stability of Turkey. The issues such as, employment, population problems, security in regional aspects, create more social problems rather than merely an ethnic problem. Due to security reasons, it is a fact that the regions of East and South East Anatolia are less developed in social, economic, employment and education than the western provinces in general. With respect to this, temporary or permanent emigrations from eastern to western provinces also bring the issues such as imbalance in distribution of population, urban construction, unemployment and issues alike.

Finally, the Kurdish question plays an important role in terms of creating the image of Turkey in the view of international organizations. Due to the ongoing conflict with the PKK and parallel to this, Turkey's policy on Eastern and South Eastern Turkey, Turkey has been criticized by the European Union regarding the violation minority rights, democracy, and human rights. The resolution of the Kurdish problem according to international law may of course be an appropriate step, but the PKK's insistence on the arms and its strategy on resolving the problem with armed struggle create many predicaments for all sides, the Kurds, the state, and the status in the international arena.

\section{References}

\section{Printed Resources}

Arfa, H. (2006). Kürtler. İstanbul: Avesta, Istanbul.

Besikci, I. (1991). Unesco'ya Mektup. Yurt Press.

Bozarslan, M. E. (1991). Mem u Zin. Istanbul.

Bruinessen, M., van. (2000). Kurtluk, Turkluk, Alevilik. Istanbul: Iletisim Yayınları.

Chatty, D. (2010). Displacement and Dispossession in the Modern Middle East. Cambridge.

Cagaptay, S. (2006). Islam, Secularism and Nationalism in Modern Turkey. Routledge.

Chaliand, G. (1993). A People Without A Country: The Kurds and Kurdistan. London.

Cormier, P. (2014). The Left in Turkey. A Fragmented History. France: Ifri.

Council Common Position. (2006). Official Journal of the European Union, p. 28

Hacettepe University Center for Population Studies. (2006) Migration and displaced population survey in Turkey. Ankara, p. 106-107.

Izady, M. (1992). The Kurds: A Concise Handbook. Routledge.

Kutschera, C. (2013). Kürt Ulusal Hareketi. Istanbul: Avesta.

Lawrence, M. (1924) The Treaties of Peace 1919-1923. Vol. 2. Carnegie Endowment for International peace. New York, p. 989.

Mikaberidze, A. (2013). Atrocities, Massacres, and War Crimes, Vol: A-L, p.746. ABC-CLIO.

Kocak, Y. (2012). Turkiye'de Göc Olgusu, Göc Edenlerin Kentlere Olan Etkileri ve Çözüm Önerileri, Kafkas University. Journal of Economic and Administrative Sciences, Vol. 3, p. 169-170.

Ocalan, A. (1999). Declaration on the Democratic Solution of the Kurdish Question. Anarachist Library, p. 85.

Ocalan, A. (1993). Kurdistan Devriminin Yolu. Köln: Serxwebun.

\section{Electronic Resources}

Abdullah Gul: Kurt sorunu Turkiye'nin birinci sorunudur. (2009). Milliyet Daily. Available at https://www.milliyet. com.tr/siyaset/abdullah-gul-kurt-sorunu-turkiyenin-birinci-sorunudur-1092779

Cemil Bayik: Ayri bir devlet istemiyoruz. (2015). Hurriyet Daily, February. Available at https://www.hurriyet.com.tr/ dunya/cemil-bayik-ayri-bir-devlet-istemiyoruz-28258176

Constitution of Republic of Turkey, Articles 2-3. https://global.tbmm.gov.tr/

Erdogan: Kurt Yok Demiyoruz, Kurt sorunu yok. (2018). Amerikanin Sesi. Available at https://www.amerikaninsesi. 
com/a/erdogan-kurt-yok-demiyoruz-kurt-sorunu-yok/4421534.html

HDP Party Charter, Article 2, Part k. https://www.hdp.org.tr/tr/parti/parti-tuzugu/10

Il il, Kurtlere ve HDP binalarina yonelik saldirilar. Evrensel news portal. Available at https:/www.evrensel.net/ haber/260224/il-il-kurtlere-ve-hdp-binalarina-yonelik-saldirilar

Institut Kurde de Paris. (2017). Available at https://www.institutkurde.org/en/info/the-kurdish-population-1232551004

Kurdistan Workers Party. Available at https://www.britannica.com/topic/Kurdistan-Workers-Party

Kurdish People Fast Facts. (2020). https://edition.cnn.com/2014/08/18/world/kurdish-people-fast-facts/index.html

Kurt sorunu benim sorunum. (2005). BBC. Available at http://www.bbc.co.uk/turkish/news/story/2005/08/050812_turkey_kurds.shtml

Library of the Congress, Washington, D.C. (2011). Vol. 6. https://www.loc.gov/item/88690896/

Managing Turkey’s PKK Conflict; The Case of Nusaybin, International Crisis Group, Europe Report. (2017). Available at https://www.crisisgroup.org/europe-central-asia/western-europemediterranean/turkey/243-managing-turkeyspkk-conflict-case-nusaybin

Progress on the situation of Kurds in Turkey? (2013). Library of the European Union. Available at https://www.europarl.europa.eu/RegData/bibliotheque/briefing/2013/130448/LDM_BRI\%282013\%29130448_REV1_EN.pdf

Selahattin Demirtas ve Figen Yuksekdag Tututklandi. (2016). Milliyet Daily. Available at https://www.milliyet.com.tr/ gundem/son-dakika-selahattin-demirtas-ve-figen-yuksekdag-tutuklandi-iste-o-cezaevine-goturuldu-2339085

Sustainable Governance Indicators. Turkey. Available at https://www.sgi-network.org/2019/Turkey/Quality_of_Democracy

Takan, A. (2015). PKK'nin Kongre Takvimi. Yenicag, March. Available at https://www.yenicaggazetesi.com.tr/pkkninkongre-takvimi-33953yy.htm

Treaty of Sevres, Article 62. Available: https://wwi.lib.byu.edu/index.php/Section_I,_Articles_1_-_260

The UN, Committee Against Torture. (2016). Available at https://www.ohchr.org/en/hrbodies/cat/pages/catindex.aspx

The United Nations, Committee on the Elimination of Racial Discrimination. (2009). Available at https://www2.ohchr. org/english/bodies/cerd/docs/A.67.18\%20English.pdf

The United Nations, Economic and Social Council, Committee on Economic, Social and Cultural Rights. (2011). Available at https://www.ohchr.org/en/hrbodies/cescr/pages/cescrindex.aspx

The United Nations, Human Rights Committee. (2012). Available at https:/www2.ohchr.org/english/bodies/hrc/docs/ gc34.pdf

Turkey 2010 Progress Report, Commission Staff Working Document. (2010). Brussels. Available at https://ec.europa. eu/neighbourhood-enlargement/sites/near/files/pdf/key_documents/2015/20151110_report_turkey.pdf

Turkey 2011 Progress Report, Commission Staff Working Document. (2011). Brussels. Available at https://www. ab.gov.tr/files/ardb/evt/2_turkiye_ab_iliskileri/2_2_adaylik_sureci/2_2_1_duzenli_ilerleme_raporlari/turkiye_ilerleme_rap_2011_eng.pdf

Turkey 2012 Progress Report, Commission Staff Working Document. (2012). Brussels. Available at https://ec.europa. eu/neighbourhood-enlargement/sites/near/files/pdf/key_documents/2012/package/tr_rapport_2012_en.pdf

Turkey 2013 Progress Report, Commission Staff Working Document. (2013). Brussels. Available at https://www. ab.gov.tr/files/2013\%20ilerleme\%20raporu/tr_rapport_2013_en.pdf

Turkey 2014 Progress Report, Commission Staff Working Document. (2014). Brussels. Available at https://ec.europa. eu/neighbourhood-enlargement/sites/near/files/pdf/key_documents/2014/20141008-turkey-progress-report_en.pdf

Turkey 2015 Progress Report, Commission Staff Working Document. (2015). Brussels. Available at https://ec.europa. eu/neighbourhood-enlargement/sites/near/files/pdf/key_documents/2015/20151110_report_turkey.pdf

Turkey 2016 Progress Report, Commission Staff Working Document. (2016). Brussels. Available at https://ec.europa. eu/neighbourhood-enlargement/sites/near/files/pdf/key_documents/2016/20161109_report_turkey.pdf

Turkiye'de en yuksek istihdam orani yuzde 55,3 ile Tekirdag'da, Bloomberg, March. (2019). https://www.bloomberght. com/turkiye-de-en-yuksek-istihdam-orani-yuzde-55-3-ile-tekirdag-da-2207323

Turkey ranks $110^{\text {th }}$ among 160 countries in The Economist's democracy index, https://stockholmcf.org/turkey-ranks110th-among-160-countries-in-the-economists-democracy-index/

Turkey's PKK Conflict. International Crisis Group. Available at https://www.crisisgroup.org/content/turkeys-pkk-conflict-visual-explainer

Yatirimin Illere Gore Dagilimi. Available at http://www.sbb.gov.tr/yatirimlarin-illere-gore-dagilimi/ 


\title{
KURDU KLAUSIMAS TURKIJOS TERITORIJOJE: GALIMYBÉS IR PROBLEMOS
}

\author{
Cinat Yilmas \\ Vytauto Didžiojo universitetas (Lietuva)
}

\section{Santrauka}

Nuo pat Turkijos Respublikos ịkūrimo kurdų klausimas buvo didžiausia Turkijos etninės mažumos problema, kuri tapo vienu svarbiausių Turkijos ir tarptautinių organizacijų darbotvarkès klausimu. Jis svarbus šalies stabilumui, kuris šiandien susijęs su saugumo ir teroro problemomis. Taigi kurdų tema valstybei yra didelis iššūkis: etninių mažumų apsauga, žmogaus teisių, demokratijos (socialinių, ekonominių ir politinių klausimų aspektais) užtikrinimas. Siekiama išsiaiškinti, kaip kurdų klausimas susijęs su šalies stabilumu Turkijos valstybės ir pačių kurdų aspektais. Šiuo tyrimu siekiama kelių uždavinių: požiūrio ị kurdų problemą vertinimas, istorinès raidos prielaidos ir problemos vertinimas šiandienos kontekste. Tyrimo metodai: lyginamoji sprendimų, dokumentų analizè, aprašomasis metodas ir informacijos medijose turinio analizè, siekiant ịtraukti aktualias naujienas. Pagrindiniai tyrimu rezultatai apibendrinti šiais kurdų klausimo aspektais: saugumo, terorizmo, mažumų, žmogaus teisių klausimų ir pan., kurie lemia Turkijos stabilumą - tiek valstybės, tiek kurdų atžvilgiu regioniniu ir tarptautiniu mastu.

Galima teigti, kad pagrindiniai kurdu judejimo veiksniai, kaip nacionalizmas, religija ir kairiujų ideologija, lemia atstovavimo jiems stoką, taigi ir kurdų klausimo sprendimo Turkijoje problemas.

Šiandien kurdų klausimo susiejimas su uždrausta Kurdistano darbininkų partija (PKK), kuri siekdama savo politinių tikslų naudoja jëgą ir grasina ją panaudoti prieš karinius ir civilinius taikinius, ir su terorizmu formuoja Turkijos politiką kurdų atžvilgiu. Turkijos požiūris ị kurdų problemos sprendimą pasitelkiant karius kuria konfliktinę atmosferą, bet nieko nesprendžia. Konfliktinė atmosfera, tvyranti nuo 1985 m., pakenkẻ abiem pusèms. Liaudies demokratinè partija (HDP) atsidūrẻ sudètingoje politinio atstovavimo situacijoje, nes tokiais klausimais kaip demokratinis konfederalizmas ir demokratinė autonomija laikosi tos pačios pozicijos kaip ir uždrausta Kurdistano darbininkų partija (PKK), nors šių dviejų organizacijų santykị bandoma diplomatiškai atskirti. Toks įvaizdis, sukurtas tiek politikoje, tiek Turkijos visuomenès akyse, lemia įsitikinimą, kad kurdų klausimas neatsiejamas nuo terorizmo.

Be abejo, neišspręstas kurdų klausimas mažina Turkijos stabilumą. Gyventojų užimtumas, regioninis saugumas lemia labiau socialines - ne tik etnines problemas. Nesant saugumo, Rytų ir Pietryčių Anatolijos regionai yra mažiau išsivystę socialiniu, ekonominiu, užimtumo ir švietimo požiūriu nei vakarinès provincijos. Dẻl laikinosios ar nuolatinès migracijos iš rytų ị vakarų provincijas kyla tokių problemų, kaip gyventojų pasiskirstymo netolygumas, miestų vystymas, nedarbas ir kt.

Galiausiai kurdų klausimas vaidina svarbų vaidmenį kuriant Turkijos ịvaizdį tarptautinių organizacijų akyse. Dèl vykstančio konflikto su PKK ir su tuo susijusios Rytų ir Pietryčių Turkijos politikos, Europos Sajunga kritikavo Turkiją dẻl etninių mažumų teisių, demokratijos ir žmogaus teisių pažeidimo. Kurdų problemos sprendimas remiantis tarptautine teise, žinoma, gali būti tinkamas žingsnis, tačiau PKK reikalavimas ginklų ir jos strategija sprendžiant ginkluotos kovos problemą kelia keblumų visoms pusėms - kurdams, valstybei, jos pozicijai tarptautinèje arenoje.

PAGRINDINIAI ŽODŽIAI: Turkija, kurdai, Kurdistano darbininku partija (PKK), Ocalan, Teisingumo ir plètros partija (AK).

JEL KLASIFIKACIJA: K1, D74, D78

Received: 2020-03-17

Revised: 2020-04-17

Accepted: 2020-05-11 